\author{
Ryszard W. Kluszczyński \\ ○ https://orcid.org/0000-0003-1073-9805 \\ University of Łódź \\ ryszard.w.kluszczynski@uni.lodz.pl
}

\title{
THE WORK OF ART AS A COLLECTION. VIOLENCE, DEATH AND LOSS IN THE ART OF LUZ MARÍA SÁNCHEZ
}

\begin{abstract}
In this article, I discuss the art of Luz María Sánchez, proposing to approach it through the conceptual category of what I term a collection or multiform artwork. I characterize the central themes of her work - violence, death and loss - and highlight the most important characteristics of her artworks, which include multiformity, fluidity, transgressiveness, transdisciplinarity, participativeness and interactivity. I likewise focus on her art's status as artistic research and its structural and material grounding in databases and collections, as well as on its use in the context of the visual arts of sound, ethnographic research, cybercartography, subversivity and found objects.

I explain how Sánchez's art is research-interventionist in nature: she analyses social events, processes and various forms of power, focusing in particular on different forms of violence. Her works emerge from research-analytical activities based on the materials she collects and the databases she builds, which serve as the foundation for the resulting artworks.

Sánchez's political interests are an expression of indignation and concern at the same time; they express both an activist stance and ethical commitment. In her art, she addresses the fate of Mexican society which has been abandoned by state authorities and left to the mercy of drug cartels and gangs. At the same time, she develops her own personal discourse in the works she creates, discreetly telling her own story which is intertwined with the history of contemporary Mexico. Her works/collections depict a landscape after a catastrophe, expressing a sense of hopelessness and loss. At the same time, however, they paradoxically initiate or promote actions and tactics of resistance.
\end{abstract}

Keywords: Luz María Sánchez, transdisciplinarity, work/collection, artistic research, multiformity, memory, artistic database, artivism 


\section{Introduction}

On 11 December 2006, the newly elected (sworn in on 1 December) President of Mexico, Felipe Calderón, announced a declaration of war against the country's drug cartels, calling on the army to assist the police in fighting them. Tens of thousands of soldiers took part in numerous operations. Yet, on 30 November 2012, when Calderón left office, the country's drug trafficking industry was as strong as it had been at the outset of his presidency. By contrast, a real, concrete result of the drug war was the deaths of at least 60,000 civilians who lost their lives as a result of this campaign. The cartels under attack by the state responded with an increase in aggression against the civilian population that was unprecedented in scale and which then became a new feature of their criminal activity. Civilians were hostages in this war. ${ }^{1}$ As a result of the cartels' war against the Mexican people, violence spread to all parts of the country, impacting the lives of people everywhere. These tens of thousands of civilian victims were the real victims of a war in which they - like the vast majority of society - were not active participants. This war being fought in the name of Mexican society was ultimately lost by the state which forsook its obligations to its citizenry ${ }^{2}$ in the face of increasing, ever more pervasive levels of violence.

Luz María Sánchez's work detritus is embedded in the very nexus of these events. This multiform, transmedia and transdisciplinary work was created between 2011 and 2015; however, the temporal structure that characterises it is more complex. The work represents a form of artistic research, so the chronology of its creation includes the time period during which the relevant research was conducted, i.e. from 2009 to the end of 2013. The research was related to the period of Felipe Calderón's presidency and the war he fought against cartels during his six-year term in office (2006-2012). Thus, as the artist initiated her research in the midst of Calderón's presidency, her work spanned a bidirectional timeline: it moved backwards, with data being collected from the first years of his presidency, and forwards, with Sánchez recording current events and using them in future works. In its early phase, the research did not yet anticipate what form of artistic representation the project would take; this crystallised in 2011. These three periods therefore define the temporal parameters of Sánchez's work: the subject of the research itself (11 December 2006 to 30 November 2012); the period during which the research was carried out

1 L.M. Sánchez, Vis.[Un]necessary force, in: Archiving and Questioning Immateriality. Proceedings of the 5th Computer Art Congress, ed. E. Reyes-Garcia, et al., Europia Productions, Paris 2016, pp. 240-241.

2 I particularly want to emphasise the place of women in this story, for violence against them and murder - femicide - have become the misfortune and scourge of Mexico. 
(between 2009 and the end of 2013) and the time between when work on the piece began in 2011 and when it was finally completed in July $2015 .^{3}$

\section{detritus - a research project}

The artist's initial, primary research objective in detritus was to identify how violence is reflected in the news media. In the work, she showed images that the media had introduced into the nation's social consciousness of the ever-growing wave of violence. These images permeated the fabric of everyday life, revealing the increasingly important role that violence had begun to play in the country. Sánchez's project provided a means for her to identify and depict the process of normalising violence in Mexico. In creating her project, she analysed magazines and extracted data from them, concerning the drug war and related violence. The information was collected in a database that contained news articles and accompanying photographs. The archive also contained data related to the photographs, such as headlines, captions, source information, web addresses, publication dates and descriptions. The images were processed using simple photographic processes and became the visual foundation for the resulting work.

It is worth mentioning that before taking on this task, Sánchez already had not only years of artistic accomplishments and university research work to her credit, but also extensive journalistic experience. She had previously worked in radio and later, including the period when she was working on detritus, in television. She thus had a full understanding of how news programmes are produced. She combined these skills and knowledge in her work, creating a hybrid, transdisciplinary work in which art met science, technology and social, political and civic issues.

Early in her research, Sánchez explored the content of various newspapers published in Mexico and available online. However, when it later turned out that some of these online sources had disappeared or become inaccessible, she narrowed her research to just two national Mexican newspapers, Milenio and Jornada, which were available online during the entire period covered by her project, analysing all the issues published from 11 December 2006 to 30 November 2012. In doing so, she was forced to exclude some of the material she had previously collected. The database she created ultimately contained 15,585 entries.

Although both the artist's research aims and results, as well as purely artistic dimensions all played an extremely important role in the work's formation

3 See http://detritus.mx/visualizacion.html (accessed: 10.07.2021). 
and functioning, the decision to limit the scope of the collected resources was justified here solely by the research aspect of the work, based on the needs of science. From the point of view of the work's aesthetics, such a measure was unnecessary because it did not affect its essential character (although, of course, it had consequences for the visual construction of the work, primarily by limiting its content and - potentially - its variety). However, it was necessary from the point of view of the research being conducted. By limiting the material analysed to the content of just the two national dailies (from which she still managed to collect nearly 16,000 entries) that were published throughout the entire period under study, Sánchez was able to conduct reliable research on the dynamics of the development and expansion of representations of violence in the media - representations which illustrated the expansion of real violence in Mexican society. Moreover, in the course of the research, it became clear that the intensity of the presence of violence in the media varied not only according to the intensity of its occurrence in reality, but also due to other factors. Many journalists were murdered by cartels during this period and violence presented in the media also affected those who exposed and depicted it in their professional work. The authorities themselves (various types and levels) were also often reluctant to publish information about the violence, sometimes out of fear of exposing corruption in which they were involved, other times out of reluctance to document their own helplessness and ineffectiveness. In 2010, President Calderón issued an appeal to the media to refrain from presenting and commenting on the violence arising out of the drug wars. Many editors heeded this call. The results of Sánchez's study thus also show the extent of interference by state institutions in the social circulation of information on violence. This second aspect of the research revealed that people in positions of political power, for various reasons of self-interest, manipulate messages about important issues, with the result that the public, deprived of important knowledge about their own situation, has limited influence over their own destiny. Full access to information is a condition for real participation in social life and for the ability to make the right and good decisions for oneself. The results of the research concerning the influence of the state on the circulation of information on violence (and many other related issues), which revealed that the news media had ceased to report on events in a reliable way, opened Sánchez's work up to other problems which she took up in subsequent works (I will return to this issue later). They also influenced her choices regarding the status of the works she created, their nature and the interrelationships between them.

I stated earlier that in her work Sánchez carried out an analysis of the process by which violence became normalised in Mexico. However, her research intentions did not stop there, just as her work is not limited to the presentation of research findings on the escalation and social assimilation of violence. 
It goes further. The images the artist collected represent Mexico's political and human landscape. They speak of the defeat suffered by the Mexican state and its social consequences: the loss of a sense of security, trust, certainty of one's future prospects and, increasingly, of life itself. Many of the most important aspects of the life of Mexican society began to take place - as a result of this failure - in the absence of the state. For this reason, the artist uses the term "post-national" to describe the condition of life in Mexico and the omnipresent violence there. ${ }^{4}$ Loss - the dominant theme of detritus - emerges here as perhaps the most important issue in Sánchez's work. I will therefore return to this thread several times in the course of my reflections here.

This interpretation of the work also explains its name - detritus: what remains, remnants, debris. A landscape after a catastrophe.

\section{The artwork as a collection}

As I have already mentioned, detritus is internally differentiated, transmedial and transdisciplinary in form. The artist herself notes that the work communicates through three different means of expression. I would say that what we are actually dealing with here are three interconnected forms of the work or even three works that are specifically related to one another, but also simultaneously separate and paradoxically autonomous. This latter claim is supported by the fact that these works usually appeared at exhibitions singly, rather than all together, where each functioned as a complete work rather than a fragment of a larger whole. The first work is a soundless video projection of all 15,585 images uncovered during the research, subsequently processed and then presented in random order at two-second intervals. The second work is an explorable interactive website where the same images, albeit experienced differently (different media lead to different experiences) are accompanied by all the other data collected during the research. The third one is a series of thirty large-format, multi-layered, colour analogue silk-screen prints, also compiled from the database/collection of 15,585 images. I would add that, alongside the three forms of the work noted by Sánchez, there are also drawings that share a common source with all the other works. However, these have been placed by the artist within the framework of another project she is currently (2020-) working on: Post Corpus which also deals with violence and the representation of violence.

From the multiplication of Sánchez's work described above comes the first and fundamental justification for the phrase used in the title of this article: the work of art as a collection. Another term that I will also use here as

4 L.M. Sánchez, detritus $1 \& 2$ and V.F(i)n_1\&2: The Sounds and Images of Postnational Violence in Mexico, https://soundstudiesblog.com/2015/04/13/detritus/ (accessed: 02.07.2021). 
synonymous is multiform artwork. ${ }^{5}$ This is because I recognise that all of the above-mentioned works (or variants of a work) combine to form what I call a collection. Together they constitute the artwork/collection called detritus. Each of them also bears the same name (sometimes their separate status is indicated by their numbering: detritus, detritus. 1, detritus. 2 - however, this is not a rule applied to all their realisations). A second additional justification is that at the core of all of these works there is a database, a collection of images, texts and information, which stems from artistic research and was created by the artist. Both dimensions of detritus's status as a collection are characterized by fluidity which is characteristic both of each of the variants of the work/ collection and of the collection as a whole. The fact that the whole artwork/ collection is fluid is determined not only by the variability of its component variants and their structural and material openness, but also by the non-finite character of the collection as a whole, which can be modified at any time by the appearance of a new variant of the work. The work/collection defined in such a manner belongs to a broader field of artistic phenomena in which we find instabilities in the form of a work of art, its being realised in various manifestations, reflecting its changeability or development. In this field, apart from the idea of multiples (see footnote 5 below), we can also include the concept of prototyping a work of art or a work in progress. However, these concepts emerge from separate sources, pursue different goals and differ in the structure of the works they delineate.

The fluidity and instability of the individual works that comprise the detritus collection is evident, for example, in the fact that they are presented in different forms at different exhibitions. Sometimes the differences are due to the fact that the work appeared at a time when the research process had not yet been completed and referred to an as-yet modest database. For this reason, for example, the exhibition of detritus at the Laboratorio Sensorial in Guadalajara, Mexico, in 2011 contained only 530 images.

Sometimes, however, these differences are a product of how concepts related to the presentation of a work later influence other conceptual aspects.

5 I want to point out that the concept presented here is not related to the idea of works/multiples (originally attributed to Marcel Duchamp), proposed in the 1950s by a group of artists, above all Victor Vasarely and Daniel Spoerri. The idea of multiples, apart from significant definitional differences from the concept of the artwork/collection proposed by me, aimed, unlike the tendency considered here, at democratising art and primarily concerned the art market. It is worth noting, however, that what was probably the first project under this initiative was called "Kollektion 58". It contained 100 objects made by over a dozen artists, but because "the individual pieces [of the collection - RWK] were diverse, it was therefore 100 versions of one idea." Different concepts sometimes lead to similar realisations; see René Block, Reminiscences of Attempts to Democratise the Art Market, "Occasional Papers" no. 10, ASP Gdańsk 2013, p. 3. 
At the same exhibition in Laboratorio Sensorial, the images projected were accompanied by an eight-channel soundtrack based on a recording of a speech by President Calderón in Washington (11 May 2011) that was then heavily processed, almost to the point of abstraction, and a monitor screen showing other images and texts (this was during a very early stage of the work). At the exhibition Forbidden to Forget at the MAC Museum of Contemporary Art in Bogotá, Colombia (6 February to 3 March 2016), detritus appeared only as a soundless projection on the building's façade, while at the exhibition Ex Convento del Carmen in Guadalajara, Mexico (14 July to 30 August 2017) - as three silk-screen prints.

A different situation occurs when two variants of a work belonging to the same collection are exhibited. They then merge into one, revealing very clearly the fluidity both of the individual forms of the work/collection and of the whole. Such a presentation was seen in the exhibition at the She Works Flexible gallery in Houston, Texas (18 September to 9 November 2015), where Detritus took the form of a soundless projection and three screen prints.

Another type of a connection/expansion occurs when elements foreshadowing another work by Sánchez that is still in the making are introduced into the structure of the detritus installation experience. In the exhibition Mapping Sound and the Urban Space in the Americas at the Bibliowicz Family Gallery in the Milstein Hall of Cornell University in Ithaca, New York (November 2014), twenty black toy guns with built-in speakers and memory cards containing the sounds of gunfire appeared alongside the projections. The presence of the guns foreshadowed the installation VIS./Un]necessary Force_l (short name: V.[u]nf_l) a year later, but at the same time, as part of that exhibition at Cornell University, from a temporal perspective, it merged with detritus to form a temporary, expanded version of this work. Research on V. [u Jnf_l was not yet complete at the time and the database in which the new work would be embedded did not yet exist, so the first draft of V.[u]nf_l (at that time still lacking its own name) merged with detritus at the exhibition, broadening the spectrum of its experience to include sound, participation and interaction. The title of this momentary whole enumerated the components of the work:

\section{detritus.2: The Sounds and Images of Postnational Violence in Mexico 20 sound devices (plastic/Caracal shaped) made in China intervened-images database.}

Previously, in the exhibition Police Frequencies.01 + detritus at the AN Studio in Mexico City (22-30 April 2012), the installation-projection detritus was juxtaposed with the sound work Police Frequencies. Both of Sánchez's works this time remained separate in the exhibition, but important interrelationships 
were formed, resulting from their kinship. Both works had been constructed from found material (Police Frequencies is constructed from a recording of intercepted radio conversations between police headquarters and the staff of a police station being attacked by bandits) and were also linked by the theme of betrayal and abandonment (similarly to civilian victims of violence, the police officers from the station did not receive any support).

Both of these situations indicate how in Sánchez's art the boundaries defining which works are part of the same collection are also blurred and fluid; works juxtaposed in an exhibition are thus able to enter into essential relationships, yielding a rich and varied, yet homogeneous statement. The structural affinity that exists between them (multiformity, fluidity, transdisciplinarity, a grounding in archives/databases) and the commonalities among the issues addressed - in particular, multiform violence and the theme of loss which is central to all of these works - generate the energy of mutual reference and interaction, as well as collaborative relations during their exhibition.

The appearance in the same exhibition of two works by Sánchez - detritus and Police Frequencies - which merged during the exhibition into a temporary impermanent whole, as if for a moment to form a new work, prompts additional reflections. Their being brought together on occasion contributed to the development of and commonalities within the spectrum of experience offered by each of them individually. The visual aspect merged with the aural aspect and the various dimensions of violence, betrayal and abandonment merged as well. One could say that in such a situation (and in a sense this also applies to other presentations of Sánchez's works cited herein), the exhibition essentially becomes the work presented. One could consider such integrated exhibitions to be yet another dimension of the concept of the artwork/collection being considered here, i.e. the multiformity of a work of art. This example furthermore reveals an important dimension of the transgressive/integrative practices that characterise Sánchez's work. The multiplication of the work, as well as its transmedial attitude and aesthetics lead to an analogous expansion of the themes and issues addressed, the ways in which they are addressed, and the disciplines brought into play. The work achieves its integrity by means of its transdisciplinary dimension, operating by means of a common language on all of its levels. The various works presented at an exhibition can, in this manner, be linked with one another through shared discursive features.

In another text ${ }^{6}$ where I also deal with the issue of the pluralisation, multiplication and multiformity of works, I pointed out that, apart from individual decisions of the artist, this tendency has three sources. The first of these are

6 R.W. Kluszczyński, Dzieto sztuki w erze sieciowej prezentacji (The Work of Art in the Age of Networked Presentation), "Czas Kultury” 2021, no. 3. 
new technologies and new media arts which, due to certain key properties, such as numerical representation, modularity and variation (as pointed out by Lev Manovich ${ }^{7}$ ), display a tendency to generate fluid works appearing in different variants. The second source is conceptual art in which an emphasis on discursivity leads to a shift in attention from the materiality of artefacts to ideas that somehow replace them. The third source is installation art in which the practices of installing a work of art facilitate its multiformity from the very outset.

An analysis of Luz María Sánchez's work points to two further, very important sources of its pluralisation and formation of the phenomenon of the artwork/collection. These are the concept of art as artistic research and artivism - art for social change. Both tendencies are linked by their transdisciplinarity and the integration of the artistic creative process with concepts and practices belonging to fields of social practice other than art. As a result, a work of art produced within the framework of such a tendency - hybrid in character and focused on research, social or political goals - tends to appear in different forms, depending on the time or place of its presentation, or the stage of advancement of the research or social work. As in conceptual art, the focus on problems, ideas and research challenges makes the work unstable, fluid, able to assume different forms and insert itself into different media.

In Sánchez's work, we can speak of the co-occurrence of at least four of these sources. Artivism and artistic research are used in combination with new media tools and work methods, as well as - in most of her works - the properties of an installation. However, as I see it, the latter pair of features merely support activities linked to the first pair. Sanchez's use of artistic research as an instrument for social action is the primary (and sufficient) reason for making the works multiform in character and giving them the status of a work/collection.

The transmedial character of detritus is expressed in the fact that although each form of the work is linked to a different medium, they all emerge from the same source - a database created by the artist as a result of her research. No single medium is used exclusively in presenting the work, nor does any one dominate. I would say that in such a situation, all of the media act as specific interfaces that link each of these autonomous manifestations of the work to their common source - database. ${ }^{8}$ Each of these works emerges from mutual

7 L. Manovich, The Language of New Media, The MIT Press, Cambridge Mass. 2001.

8 In another place I write about a similar situation that I found in the work of Masaki Fujihata, see R.W. Kluszczyński, Towards Augmented Reality. An Introduction to Reflections on the Art of Masaki Fujihata, in: Augmenting the World. Masaki Fujihata and Hybrid Space-Time Art, ed.

R.W. Kluszczyński, Laznia Center for Contemporary Art, Gdańsk 2017, p. 15. 
references that exist between the medium/interface and the source, references that are activated in the experience of their reception. Their transdisciplinarity, in turn, is a product of active interrelations that arise through the creative process and the resulting artwork - a product of all the channels of social action involved therein: art, technology, humanistic/social research and political, civic engagement which together lend to the work its research/artistic format.

All of the observations, analyses and interpretations of Sánchez's work I have presented thus far highlight the importance of research status in terms of the overall structure and characterisation of each of her works, and of how, in each case, this leads either to new knowledge or some form of social intervention (or both). The fact that a work of art has the character of artistic research is, above all, particularly and directly significant in terms of the cognitive discourse which it then to some extent becomes, and of the knowledge it builds or negotiates as a result. However, this is by no means without significance for the artistic dimension of the work. On the contrary, a work of art's status as artistic research plays a very important role in terms of how it is conceived. Research choices inevitably have important consequences for its form, content and aesthetics, significantly influencing the formation of the overall aesthetic experience offered by the work. ${ }^{9}$ The research dimension of an artistic work also has formal and aesthetic significance, which should be kept in mind when reflecting on art of this kind. All artistic discourses, whether they be research-, activist- or art-oriented, should ultimately be considered together, in their mutual relations and connections, when they meet within the framework of a single artwork. It is necessary in research to use methods and languages that embrace and integrate all relevant aspects, allow us to see their interdependencies, and make it possible to speak about art as an artistic form of research and socio-political activity. This last term leads me to emphasize once again, as I reach the end of this part of my discussion, that in the case of detritus, as in Luz María Sánchez's whole oeuvre, her activist intention and actions for change are the essential extensions of her cognitive interests. Her artistic research is thus both ethical and political in nature.

\section{Creativity amidst violence, death and loss}

The multiform installation detritus, which by its very nature prepared the grounds for subsequent works that were continuations of Sánchez's program-

9 The crisis of the concept of aesthetic experience noted in the 20th century and the growing awareness of the need to redefine it owe a great deal, in my opinion, to the processes by which art has become a transdisciplinary phenomenon, including artistic research practices; cf. R. Shusterman, The End of Aesthetic Experience, [in:] Idem, Performing Life. Aesthetic Alternatives for the Ends of Art, Cornell University Press, Ithaca 2000, pp. 15-34. 
me to create a multiform artwork/collection focused on the issues of violence and loss, in a way was a product of her earlier works itself, in particular 2487.

In her eight-channel sound installation 2487 (2006), whose title signifies the number of recorded fatalities among those attempting to cross the border between Mexico and the USA between 1993 and 2006, the artist used various sources to construct a database containing information on the loss of life on the Mexican-American border. In the work, the artist speaks the names of all 2487 victims of institutional political violence (what else but political violence can we call national borders in today's world, where one's identification with a place is systematically undermined in various ways) who she had been able to access information on (the estimated full number is much higher). Each name was recorded in a separate sound file (lasting three seconds), accessed by the installation in a random order, building in its space sound structures whose dynamic aesthetics reproduce the disorderly processes of social migration, becoming, as a result, an original form of migration aesthetics. The artist's action, reflected in the voice performance of reading the list of names, is both discreet and poignant, minimalistic and expressive, triggering strong emotional reactions in the audience. ${ }^{10}$ The installation also includes a book containing all the names of the victims along with their place of origin, age, date and cause of death, if known. ${ }^{11}$ Another important visual component of the installation is a graphic score which illustrates the functioning of the system that randomly generates the voice performance.

The nature of the work allows for different forms of presentation. The presentation at San Antonio Artpace (2014-2015) occurred in a gallery setting. A white bench placed there, intended for the audience, was surrounded by sixteen low-lying white speakers. The organisation of the space encouraged a contemplative relationship with the work, highlighting its commemorative nature. At Fort Winfield Scott in San Francisco (2016), in contrast, the installation was located in a bunker, where speakers were placed along a corridor. The movement of the audience within the installation space thus became an important factor in how one experienced the work and the nature of the meanings negotiated.

There is also a second version of this installation that takes a participatory form, in which the names of the victims are spoken by different voices of men, women and children. This version provides a different form of expression thanks to the diversity of the voices used, which corresponds to the multiplicity and diversity among the victims. This second version strongly emphasises the

10 Cf. D.I. Cassilas, Listening to the Border: "2487: Giving Voice in Diaspora" and the Sound Art of Luz María Sánchez, "Sounding Out", 4 July 2011, https://soundstudiesblog.co$\mathrm{m} / 2011 / 07 / 04 /$ listening-to-the-border-2487-giving-voice-in-diaspora-and-the-sound-art-of-luzmaria-sanchez/.

11 Cf. M. Agresta, Narco Violence, as Seen by a Journalist-Turned-Artist, "Texas Observer", 5 Nov. 2015. 
communal nature of the individual experience of death, making it clear that the death of an individual also results in the severing of social bonds, leaving a gap and generating a sense of loss in others.

Sánchez has given her work a commemorative character and function, both by lending her own voice to the dead and by creating the community of voices commemorating them.

The installation 248712 is the first of two parts of the installation Diaspora $I / I I$ (2006). Its second part, riverbank, is dedicated to the survivors. It consists of a sculpture made of found clothing and personal effects, i.e. an arrangement of things found by Sánchez during a series of expeditions along the riverbank near Laredo, on the American side of the border, in 2006. They were abandoned by immigrants who had successfully managed to cross into the US via the Rio Grande River which marks the border with Mexico. Some of these objects are pieces of clothing which the immigrants replaced with new ones after crossing the river, in order to blend in and start a new life. However, they also symbolise the loss of their previous lives in all their aspects, not only those which were unwanted and have now been abandoned, as well as the loss of their previous identity which had to be established anew.

Both works, which together constitute the installation Diaspora I/II, fit into the framework of multiform art and the concept of the artwork/collection, both together - as two separate works that merge into a whole as another work - and separately. Separated, each is grounded in its own collection (a named database or collection of gathered objects) and each appears or can appear in different forms. While maintaining an unambiguous, profound and moving tone, they are characterised by fluidity, non-finality and formal openness that favour their multiform presentation. Violence and loss are at the very centre of their field of meaning.

Diaspora also exists as a specially produced box (five numbered copies), comprising both 2487 and riverbank, including a curatorial text, a CD of a performance of 2487 , a book containing data on the people who lost their lives at the border, a graphic-score showing the structure used to generate the voice performance and photographs referring to the riverbank project.

I mentioned earlier that, in her work on detritus, the artist's discovery of the media's unreliability in reporting events concerning violence and the drug war turned Sánchez's work towards new issues. Forms of social activism that had replaced non-functioning institutions of the state became the new object of her attention. In Mexico, where the authorities have tried to limit the circulation of information on events and problems, particularly those to which her

12 There is also an online version of the work, see: https://www.diaspora2487.org (accessed: 09.07.2021). 
works refer, civic activism plays an extremely important role and, like Sánchez's work itself, is of great political significance. Her works form a perfect model for the interpenetration of the artist's individual perspective through a social perspective, the creative use of collectively acquired material. This permeation occurs both at the level of the work's structure and in the methods used to obtain, process and utilise information.

From within this circle of issues emerged Luz María Sánchez's multiform artwork/collection Vis.[un]necessary force, conceptually preceded by detritus. It has four basic autonomous manifestations, each of which also appears in exhibitions in multiple incarnations.

In the transmedia installation Vis.[un]necessary force_l (2014-2015) and Vis.[un]necessary force_1.01 (2017), the artist placed sound sources (sound cards and speakers) inside purchased plastic models of guns or, in another version of the work, in specially prepared sculptural forms, created using an additive method (additive sculpture, 3D printing), in the shape of guns (Caracal F 9x19 mm). The sounds used had been previously collected in an archive prepared by the artist, from which the work grew: these were the sounds of gunfire in or near which random people found themselves, recorded the events and sounds with their smartphones, and then uploaded the recording onto YouTube. These individuals thus performed the role of a citizen journalist, replacing Mexico's poorly functioning media institutions. Having researched social media, including YouTube, from which she downloaded the transcripts, the artist built a database for the work.

The installation is participatory in two important respects - in terms of production, because the sound data was created by numerous specific people who thus contributed to the work and in terms of the experience of reception, as it is the audience who determines how the installation is to be used. The work also provides information on the sources of the sounds being listened to, both in the form of a map and in detailed descriptions of the recorded events.

By leaving it up to the audience to decide which processes to set in motion in the installation, the artist not only emphasises its participatory nature but also introduces an interactive aspect to it: the way the work is experienced depends on the interactive behaviour of each viewer. Thanks to this interactivity, Vis.[un]necessary force_1. and 1.01 can be experienced in many ways. Participation and interactivity become important aspects of the work/collection for Sánchez.

Furthermore, in addition to the various work/installation and gallery forms, there is also an interactive virtual version on the Internet ${ }^{13}$, which further develops the multiformity of the work.

13 See: http://vis 1.vis-fuerzainnecesaria.org (accessed: 10.07.2021). 
In all of the abovementioned installations by Luz María Sánchez: 2487, Vis.[un]necessary force_l and Vis.[un]necessary force_1.01, the use of sound is asynchronous (as was the projection of images in detritus). However, while in the former this asynchronicity has its source in the random nature of its generation (technical aspect), in the latter it results from the unstructured free behaviour of the audience (human aspect). Thus, the experience of the two works is distinctly different, which also affects the way in which their multiformity is experienced.

A special place in Luz María Sánchez's work is also occupied by the project Vis.[un]necessary force_2 (V.[u]nf_2), developed since 2015 as a work in progress. The work is a form of support for orphaned children whose parents were victims of organized criminal violence and constitutes a supplement to their therapeutic activities realized through artistic action, the use of technology and creation of safe spaces. ${ }^{14}$ V. [u $] n f \_2$ in its final form is a series of 3D sound sculptures that emerged from the therapy (creative interaction with children). However, I do not see this artwork merely as a final installation, as it encompasses all stages of the artist's work in this area, giving the whole a deeply multiform character and building another work/collection within a wider structure of the same kind: Vis.[un/necessary force.

Sánchez collaborated with psychologist Verónica Castillo Arnal who runs a non-profit organisation in Ciudad Juarez, Mexico, where she works with children suffering from post-traumatic stress disorder. The artist integrated her art project into Arnal's therapeutic process, in accordance with the principles of art therapy. In her collaboration with Castillo Arnal, Sánchez transformed drawings made by the children during therapy into $3 \mathrm{D}$ objects - sound sculptures that constitute the content of the installation. Replicas of these objects remain in the environment where the children's therapy takes place. An important element of the project was the connection between the sculptures and sound autonomous digital audio devices were built into the sculptures, allowing each sound sculpture to independently play back the children's previously recorded voices, constructing the work's aesthetics and enhancing its therapeutic potential.

In her work V.[u]nf_2, Sánchez integrated many of the qualities characteristic of her art - critical analyses of violence processes, participatoriness, transmediality, linking images and objects with sound, and the creation of databases - with sociological, psychological and therapeutic research, and implementation perspective. This allowed her to create a work with a complex transdisciplinary profile which, at the same time, can serve as an easy-to-use

14 https://www.vis-fuerzainnecesaria.org/v-u-nf-2 (accessed: 10.07.2021). 
tool to help suffering children. The artist assumes that her project can also be replicated in other therapeutic institutions in Mexico. ${ }^{15}$

Another work from the Vis collection - a mobile app linked to a dedicated website, Vis. [un]necessary force_3(2017-2021) - was offered by the artist to the Las Rastreadoras collective operating in Mexico that search for the remains of their kidnapped and murdered loved ones. Closely linked to the theme of loss, the work - an audiovisual cybercartographic form - is both a means of commemorating victims and a tool: a database for the bottom-up construction of memory, as well as oral and audiovisual histories. The data collected here are scientifically systematised. The work also serves to empower the participants and strengthen their sense of community.

Vis. [un]necessary force_3 is a transdisciplinary and collaborative creative work that builds on the foundation of ongoing research while serving communities in the organizing of their search expeditions. This linking of artistic discourse with scientific-technological and activist discourse is characteristic of Sánchez's work.

The result of one such expedition conducted by the Las Rastreadoras collective, in which the artist also participated, is her most recent work (to date) from the Vis.[un]necessary force collection, the generative sound installation Vis. [un]necessary force_4 (2019-2021) which uses, among other things, sounds recorded during the expedition.

Luz María Sánchez's subsequent works in progress: Closed Circuit (2020-), Post Corpus (2020-) and Power Room (2020-) all follow the path set by detritus and her other earlier works. For all their variety, formal richness and thematic diversity, they all continue practices organised around multi-part artworks/ collections that grow out of the artist's ongoing artistic research centred on reflections on violence, death and loss.

Detritus occupies a very important position in this context. The qualities that I find particularly important for it - multiformity, fluidity, transgressiveness, transdisciplinarity, participatoriness, the status of artistic research, structural and material grounding in databases and collections, the use of found materials ${ }^{16}$, subversiveness, as well as the central themes of violence, death and loss - can admittedly be found, to varying extents, already in the artist's earlier works, such as 2487 or riverbank. However, when they are repeated in detritus, their role is confirmed and consolidated, while the accompanying awareness of their use, function and meaning increases. In Sánchez's art, Detritus turned out to be a field of consolidation for her basic themes and, at the same time, a point

15 Ibid.

16 Throughout Sánchez's work, this characteristic has taken many different forms: found sound art, found image art, found object art, found clothing and personal effects sculpture. 
of departure, and a starting point for further work. It was here that her artistic language ultimately took shape and then found an excellent means of fulfilment in the work/collection Vis.[Un]necessary Force and subsequent works.

\section{Conclusion}

Luz María Sánchez made her mark in the art world in the 1990s. Her first artworks were linked to the field of sound art. However, her artistic output very early revealed a transgressive character. Visual works appeared among her oeuvre and then, which was a particularly important moment, multi- and transmedia works.

Sánchez's work ultimately assumed a research/interventionist character. Her artworks emerge from analytical work, from studies resulting in materials being collected and archives compiled by the artist, which serve as the foundation for the resulting works. Her artistic activity is socio-political in nature: it analyses social events and processes, and forms of governance, focusing in particular on various forms of violence.

Sánchez's political interest is an expression of indignation and concern at the same time. It represents an activist stance and an ethical commitment; it is both a research activity and a protest demanding social change. It is grassroots politics built outside of institutional structures. In her research, the artist unearths and reveals unknown or camouflaged problems and stories, deconstructs false attitudes and beliefs, and supports civic action. Among the most important themes of her work we find violence, kidnapping, human trafficking and death - all scourges of today's Mexico - which together lead to a deepening sense of loss.

She takes up these topics within the framework of artistic research, which usually results in transmedia transdisciplinary installations, projections and object-artefacts. Her artistic approach is also characterised by the use of found objects, which inevitably includes subversion, the use of sound in the context of the visual arts, participation and creative collaboration, ethnographic research and cybercartography. For the purpose of her artistic work, she conducts research, collects information and builds databases which she makes available on the Internet and uses in her works. Her research is collective in nature.

In her art, Sánchez deals with the fate of Mexican society abandoned by state authorities, inept officials (starting with two successive presidents) and corrupt officers; a society handed over to gangs and drug cartels. At the same time, however, she develops her own private discourse in the works she creates, discreetly telling her own story which is intertwined with the history of contemporary Mexico. Her time of violence, death and loss began on 19 July 1982 when, as a child, she found her father repeatedly shot and dying on the floor 
upon returning home. Her world changed forever then. In her work, she now develops the concept of the artwork as an archive/memory using strategies of engagement, focusing her attention on violence and the forms by which it is naturalised and institutionalised. Through the sound and visual archives she creates, her artworks/collections depict a post-disaster landscape expressing a sense of hopelessness and loss. At the same time, however, they paradoxically initiate actions of opposition and tactics of resistance.

Hope dies last.

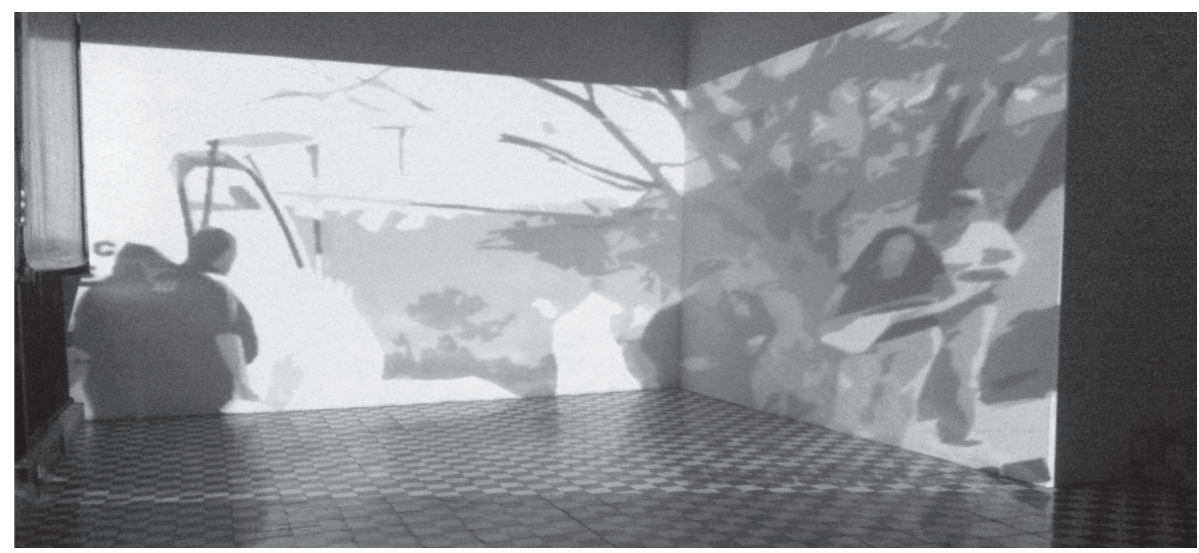

1. Luz María Sánchez, detritus, 2012; single-channel projection of 15,585 intervened image da tabase; variable dimensions; undetermined duration (detail exhibition AN Studio, Zona Maco Mexico Arte Contemporáneo [Off-MACO], Mexico City, 2012); (c Luz María Sánchez; photo: Luz María Sánchez.

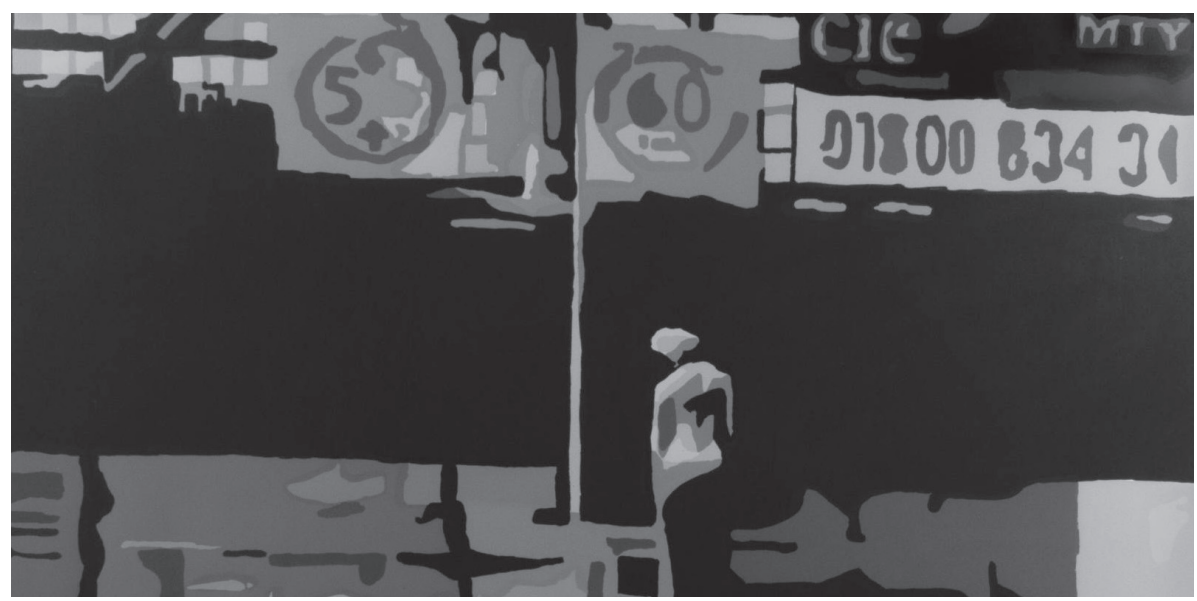

2. Luz María Sánchez, detritus, 2015; handmade multiple-ink silkscreen on Fabriano paper; from the series detritus; 140 x 120 cm; (C) Luz María Sánchez; photo: Luz María Sánchez. 


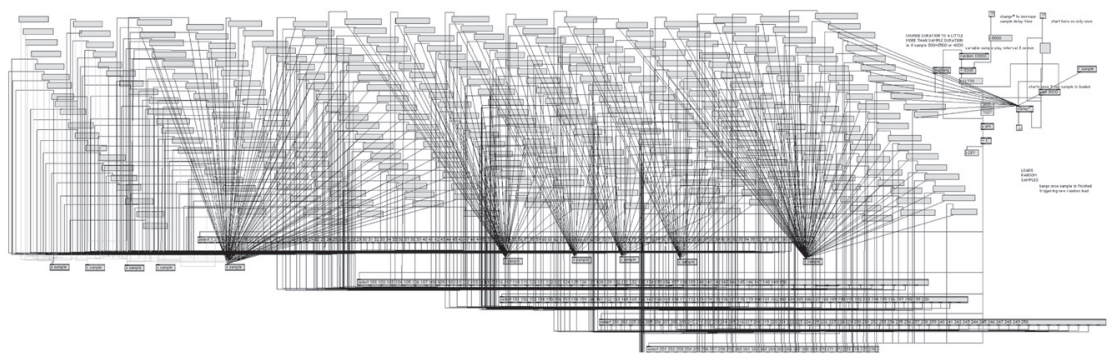

3. Luz María Sánchez, diaspora, 2006; artist container [box]: 2487 [book, sound cd, computer score], riverbank [installation photo, three on-site photographs] (detail, computer score do cumentation); originally commissioned by Artpace San Antonio; (C Luz María Sánchez; photo: Todd Johnson.

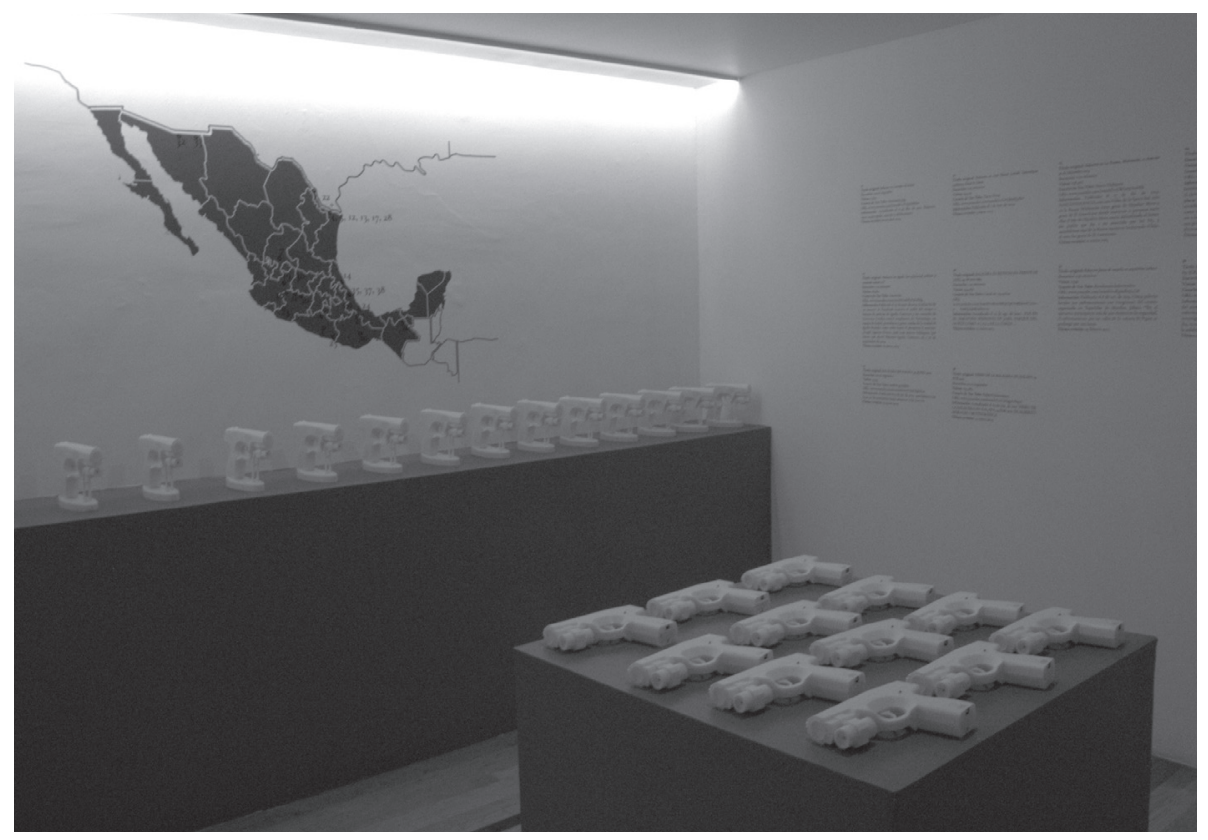

4. Luz María Sánchez, Vis. [un]necessary force_1.01, 2017-2020; interactive, participatory, multimedia installation: 100 portable white PLA digital speakers in the shape of a Caracal $9 \mathrm{~mm}$ pistol, 100 Micro-SD cards, $100 \mathrm{mp} 3$ sounds, texts, map, variable modular structure; variable dimensions; undetermined duration (detail exhibition Laboratorio de Arte Alameda LAA, Mexico City, 2019); (C) Luz María Sánchez; photo: Marcos Pérez Botello. 


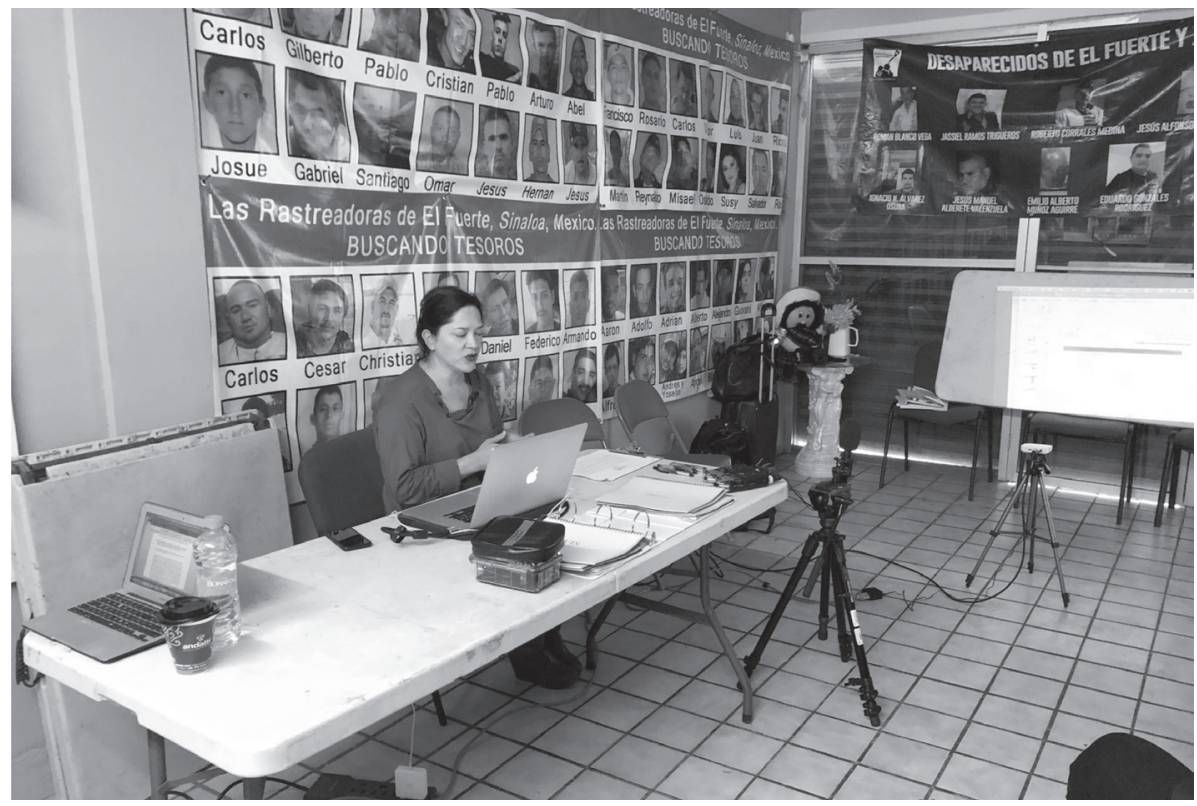

5. Luz María Sánchez during an introductory workshop of Vis. [un]necessary force_3, at the headquarters of Las Rastreadoras de El Fuerte, in Los Mochis, 2019; photo: Fernando González Buenrostro.

\section{BIBLIOGRAPHY:}

Agresta, Michael (2015) Narco Violence, as Seen by a Journalist-Turned-Artist, "Texas Observer", Nov 5, https://www.texasobserver.org/narco-violence-as-seen-by-a-journalist-turned-artist/

Block, René (2013) On Attempts to Democratise the Art Market, "Publisher's Notebook", no. 10.

Cassilas, Dolores Inés (2011) Listening to the Border: "2487: Giving Voice in Diaspora" and the Sound Art of Luz María Sánchez, "Sounding Out", July 4, https://soundstudiesblog.co$\mathrm{m} / 2011 / 07 / 04 /$ listening-to-the-border-2487-giving-voice-in-diaspora-and-the-sound-art-of-luzmaria-sanchez/

Kluszczyński, Ryszard W. (2021) Dzieto sztuki w erze sieciowej prezentacji (The Work of Art in the Age of Networked Presentation), "Czas Kultury”, no. 3.

Kluszczyński, Ryszard W. (2017) Towards Expanded Reality. Introduction to Considerations on the Work of Masaki Fujihata, [in:] Widening the World. Masaki Fujihata and the art of hybrid spacetime, ed. Ryszard W. Kluszczyński, Łaźnia Centre for Contemporary Art, Gdańsk, pp. 6-19. 
Manovich, Lev (2001) The Language of New Media, The MIT Press, Cambridge Mass.

Sánchez, Luz María, detritus $1 \& 2$ and V.F(i)n_l\&2: The Sounds and Images of Postnational Violence in Mexico, https://soundstudiesblog.com/2015/04/13/detritus/

Sánchez, Luz María (2016) Vis.[un]necessary force, [in:] Archiving and Questioning Immateriality. Proceedings of the 5th Computer Art Congress, ed. Everardo Reyes-Garcia, et al., Europia Productions, Paris, pp. 240-259.

Shusterman, Richard (2000) The End of Aesthetic Experience, [in:] Idem, Performing Life. Aesthetic Alternatives for the Ends of Art, Cornell University Press, Ithaca, pp. 15-34.

http://detritus.mx/visualizacion.html

https://www.vis-fuerzainnecesaria.org/v-u-nf-2

https://www.diaspora2487.org

http://vis1.vis-fuerzainnecesaria.org

\section{DZIEŁO SZTUKI JAKO KOLEKCJA. PRZEMOC, ŚMIERĆ I UTRATA W TWÓRCZOŚCI LUZ MARÍl SÁNCHEZ (streszczenie)}

Rozważam w tym artykule twórczość Luz Marii Sánchez. Ujmuję ją przy użyciu proponowanej przez siebie kategorii dzieła sztuki jako kolekcji bądź dzieła wielopostaciowego (multiform artwork). Charakteryzuję centralne dla jej twórczości tematy: przemocy, śmierci i utraty. Wydobywam też najważniejsze właściwości jej dzieł: wielopostaciowość, płynność, transgresyjność, transdyscyplinarność, partycypacyjność i interaktywność, status artistic research, strukturalne i materiałowe ugruntowanie w bazach danych i kolekcjach, jak również posługiwanie się dźwiękiem w kontekście sztuk wizualnych, badania etnograficzne i cyberkartografię, wykorzystanie obiektów znalezionych i subwersywność.

Uznaję, że sztuka Sánchez ma charakter badawczo-interwencyjny: analizuje wydarzenia i procesy społeczne oraz formy sprawowania władzy, skupiając się w szczególności na różnych formach przemocy. Jej dzieła wyłaniają się z pracy analitycznej, której efektem są gromadzone materiały i budowane przez artystkę bazy danych, służące jako fundament powstających dzieł.

Zainteresowanie polityczne Sánchez jest wyrazem oburzenia i jednocześnie troski, jest postawą aktywistyczną i etycznym zaangażowaniem. W swej sztuce zajmuje się losem meksykańskiego społeczeństwa porzuconego przez władze państwowe, oddanego w ręce narkotykowych karteli i gangów. Jednocześnie rozwija w tworzonych dziełach swój osobisty dyskurs, dyskretnie opowiada własną historię, która splata się z historią współczesnego Meksyku. Jej dzieła-kolekcje ukazują pejzaż po katastrofie, wyrażają poczucie beznadziei, utraty. Zarazem jednak, paradoksalnie, inicjują bądź wspomagają działania sprzeciwu i taktyki oporu.

Słowa kluczowe: Luz María Sánchez, transdyscyplinarność, dzieło-kolekcja, artistic research, wielopostaciowość, pamięć, artystyczna baza danych, artywizm 
Ryszard W. Kluszczyński, professor, $\mathrm{PhD}$, media art scholar, writer and curator. Chair of the Department of New Media and Digital Culture, University of Lodz, Poland. Professor at the Academy of Fine Arts in Lodz. He investigates the issues of new media arts and cyberculture, contemporary art theory and practices, avant-gardes, transdisciplinary cultural transformations, and recent interactions between art, science, technology and politics.

Some of his recent book publications include: Towards a Non-Anthropocentric Ecology. Victoria Vesna and Art in the World of Anthropocene (2020); Beyond Borders: Processed Body - Expanded Brain - Distributed Agency (2019); Augmenting the World. Masaki Fujihata and Hybrid Space-Time Art (2017).

Artistic Director of Art + Science Meeting Program at the Centre for Contemporary Art in Gdansk (2011-). Co-curator of the travelling international exhibition United States of Europe (2011-2013). Co-curator of the Second International Biennale of Contemporary Art "Mediations", Poznan 2010. Chief Curator of Film, Video and Multimedia Arts at the Centre for Contemporary Art - Ujazdowski Castle in Warsaw (1990-2001). 